\title{
Az energiamentes édesítőszerek hatása az egyes anyagcsere-paraméterekre
}

\author{
Hidvégi Tibor dr. \\ Petz Aladár Megyei Oktató Kórház, Anyagcsere, Endokrin és Diabetológiai Belgyógyászati Osztály, Győr
}

\begin{abstract}
Az energiamentes édesítőszerek az üdítőitalok mellett számos egyéb élelmiszerben is megtalálhatók. Az élelmiszergyártók egy-egy termékben gyakran egyszerre többféle édesítőszert, illetve édesítőszer és cukor keverékét is alkalmazzák, elsősorban a nagyobb mértékú édes íz és a kevesebb kalóriabevitel elérése érdekében. Az Amerikai Szív Társaság és az Amerikai Diabetes Társaság 2012-ben megjelent tudományos állásfoglalása szerint a cukorbevitel csökkentése az optimális táplálkozás és a megfelelő testsúly fenntartásának fontos része. Kontrollált, intervenciós vizsgálatok azt mutatták, hogy az energiamentes édesítőszerek használata során a testsúly nem változott, ső́t egyes esetekben még csökkent is. Ezt igazolta egy nemrég megjelent randomizált, kontrollált vizsgálatokat összesítő tanulmány is, amely szerint az energiamentes édesítőszerek hozzájárultak a testsúly csökkentéséhez és a testsúly megtartásához is. Az Amerikai Dietetikusok Társasága összefoglalója szerint az energiamentes édesítőszerek használata nem befolyásolja a glykaemiás választ, nem emeli az étkezés utáni vércukor szintjét cukorbetegek esetében. Az eddigi eredmények tehát azt mutatják, hogy az energiamentes édesítőszerek használata csökkentheti a szénhidrátfogyasztást, amely által az összkalória-bevitel is mérséklődhet. Használatuk elősegítheti a testsúly csökkenését/kontrollját, és az egyéb anyagcsere-paraméterek (például vércukor, triglicerid) is javulhatnak. Mindemellett fontos megjegyezni, hogy ezek az előnyök nem érvényesülnek teljes mértékben, ha kompenzáló energiabevitel-növekedés kíséri fogyasztásukat. Orv. Hetil., 2016, 157(Szuppl. 1), 8-13.
\end{abstract}

Kulcsszavak: energiamentes édesítőszerek, elhízás, diabetes

\section{The effect of nonnutritive sweeteners on certain metabolic parameters}

Nonnutritive sweeteners can be found in many other foods apart from soft drinks. Producers of foodstuffs often use a combination of several sweeteners or sweetener and sugar mixes in a single product mainly to achieve a sweeter taste with a lower calorie count. According to the 2012 Scientific Statement of the American Heart and Diabetes Association, reduction of sugar intake plays an important role in establishing an optimal diet and the maintenance of an appropriate body weight. Controlled intervention studies show that during use of calorie-free sweeteners body weight did not change, moreover, in some cases weight even fell. This was also demonstrated in a recently published summary study of randomized controlled studies, according to which calorie-free sweeteners contributed to both loss and maintenance of body weight. According to the summary of the American Dietetic Association, the use of calorie-free sweeteners does not influence the glycemic response and does not increase postprandial blood glucose levels in diabetics. The results thus far, then, show that the use of nonnutritive sweeteners can reduce the consumption of carbohydrates, by which total calorie intake can also be lowered. Their use can promote weight loss and maintenance as well as can help to improve the values of other metabolic parameters (eg. blood sugar, triglycerides). In addition to this, it is important to note that these benefits will not fully materialize if consumption of nonnutritive sweeteners is accompanied by an increase in compensatory caloric intake.

Keywords: nonnutritives weeteners, obesity, diabetes

Hidvégi, T. [The effect of nonnutritive sweeteners on certain metabolic parameters]. Orv. Hetil., 2016, 157(Suppl. 1), $8-13$.

(Beérkezett: 2016. március 7.; elfogadva: 2016. március 24.) 


\section{Rövidítések}

AIDS $=$ (acquired immune deficiency syndrome) szerzett immunhiányos tünetegyüttes; $\mathrm{BMI}=$ (body mass index) testsúlykg/testmagasság ${ }^{2}$, testtömegindex; HIV = (human immunodeficiency virus) emberi immunhiányt előidéző vírus; IDF = (International Diabetes Federation) Nemzetközi Diabetes Szövetség; NNS $=$ (nonnutritive sweeteners) energiamentes édesítőszerek; OECD = (Organisation for Economic Co-operation and Development) Gazdasági Együttmúködési és Fejlesztési Szervezet; OGTT = orális glükóztolerancia-teszt; RCT $=$ randomizált, kontrollált tanulmányok; $\mathrm{WHO}=$ (World Health Organization) Egészségügyi Világszervezet

$\mathrm{Az}$ édes íz szeretete egyidős az emberiséggel [1]. Az ilyen ételek és italok fogyasztása kellemes érzéseket kelt (anyatej, gyümölcsök, édes italok). Az ízek élvezetét számos más tényező, genetikai, szociokulturális hatások, egészségi állapot és az életkor befolyásolja. A nádcukrot már i. e. 3000-ben ismerték, elsősorban áldozati célokra használták, táplálkozás céljára Dárius perzsa király körülbelül i. e. 500-ban vezette be, arab közvetítéssel jutott a mediterrán térségbe, 1493-ban Kolumbusz Kristóf vitte Amerikába. A cukorrépából történő cukor előállítását 1747-ben Andreas Marggraf fedezte fel, ezt követően a cukor megkezdte „világhódító” útját.

A WHO 2015-ben kiadott új irányelve [2] javasolja figyelembe véve az elhízás és a vele összefüggő betegségek térnyerését -, hogy a felnőttek és gyermekek csökkentsék napi hozzáadott cukorfogyasztásukat teljes kalóriabevitelük kevesebb mint 10\%-ára. Az irányelv az élelmiszerekhez, italokhoz az ipari feldolgozás során és a fogyasztó által hozzáadott monoszacharid: glükóz, fruktóz, diszacharid: nád, maláta és répacukor, mézben, szirupokban, gyümölcslevekben és gyümölcslé-koncentrátumokban lévő cukrokra vonatkozik. Nagy-Britanniában a felnőttek átlagosan 11,6, a gyermekek pedig 15,2 energiaszázalék cukrot fogyasztanak, azaz sokkal többet a kiegyensúlyozott étrendhez szükségesnél. Magyarországi felmérések szerint a felnőttek [3] esetében kisebb, míg

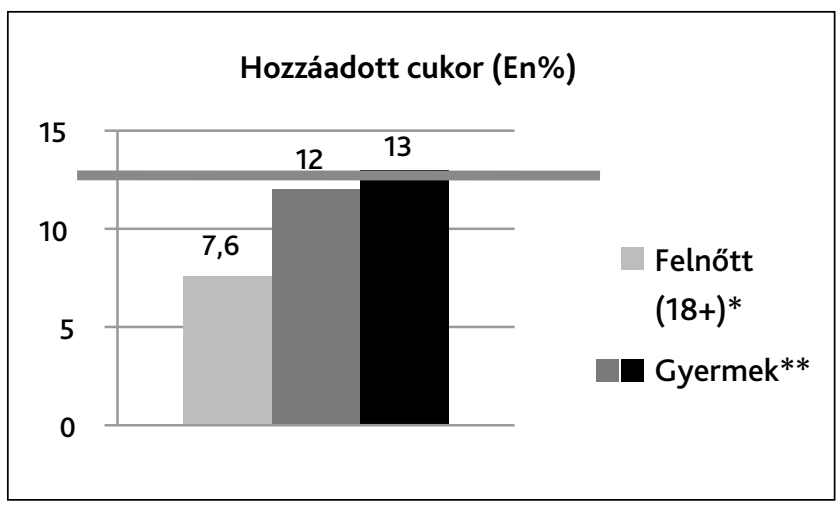

1. ábra $\begin{aligned} & \text { Cukorbevitel Magyarországon felnőtt- és gyermekkorban } \\ & (\text { En } \%=\text { energiaszázalék })\end{aligned}$
(Forrás: *Sarkadi Nagy, E. et al. [3]) (**Kiss-Tóth, B. [4]) a 4-10 éves gyermekeknél [4] a hozzáadott cukor fogyasztása nagyobb a kívánatosnál (1. ábra).

A cukorfogyasztás korlátozására világszerte elterjedt az édesítőszerek használata [5]. Az Amerikai Szív Társaság és az Amerikai Diabetes Társaság meghatározása szerint a nonnutritív édesítőszerek (alacsony kalóriatartalmú édesítőszerek, mesterséges édesítőszerek kalóriát nem tartalmazó és intenzív édesítőszerek) édesítőértéke sokkal kifejezettebb grammonkénti dózisban, mint a kalóriát tartalmazó édességek, a cukor, kukoricaszirup és gyümölcskoncentrátumok. A kalóriát tartalmazó édesítők helyett adva kisebb mennyiségben is édesítőhatással rendelkeznek, így rendkívül kevés energiát adnak vagy kalóriamentesek. Széles körben használatosak italokban, élelmiszerekben, fogkrémben, rágógumiban. A dolgozatban az energiamentes édesítőszerekkel kapcsolatos újabb irodalmi adatokat tekintjük át.

\section{Obesitas}

Az elhízás krónikus anyagcsere-betegség, amelyet a szervezetben a zsírszövet felszaporodása jellemez. Egyes esetekben átmenetet jelenthet az egészséges állapot és betegség között, de önmagában is a halálozás, a munkaképesség-csökkenés egyik vezető oka. Nemcsak a felnőtteket, hanem a gyermekeket és a fiatalkorúakat is érinti világszerte. Az elhízás epidemiológiai megfigyelések alapján járványszerűen terjed [6]. A WHO állásfoglalása szerint az elhízás sokkal súlyosabb probléma Földünkön, mint az alultápláltság. 2014-ben több mint 1,9 milliárd felnőtt (18 év feletti) volt túlsúlyos, ebből 600 millió elhízott. Az 5 év alatti gyermekek közül 42 millió volt túlsúlyos vagy elhízott. Az európai régióban az elhízási ráta felnőttek esetében $21,5 \%$ a férfiaknál és 24,5\% a nőknél. Ugyanebben a felmérésben az 5 év alatti gyermekek 12,4\%-a volt túlsúlyos. Az adatokat előrevetítve, a világ lakosságának 60\%-a, mintegy 3,3 milliárd személy lehet túlsúlyos (2,2 milliárd) vagy elhízott (1,1 milliárd) 2030ra, ha a trend folytatódik.

Az OECD (Organisation for Economic Co-operation and Development) Gazdasági Együttmúködési és Fejlesztési Szervezet felmérése alapján [7] Magyarországon az elhízás aránya a legnagyobb a régióban, mind a felnőttek, mind a gyermekek körében. A túlsúlyos személyek arányát az OECD-régióban a 2. ábra illusztrálja. Minden második felnőtt túlsúlyos, öt személyből egy elhízott. A 13-14 év közötti gyermekek közül négyből egy túlsúlyos. Több férfi túlsúlyos hazánkban, mint nő, de az alapfokú végzettségű nők között 1,7-szer nagyobb az elhízás aránya a felsőfokú képzettséggel rendelkezőkhöz viszonyítva. Felnőttekben az elhízás BMI szerinti kategóriáit (WHO, 1997) az 1. táblázat mutatja be.

Az elhízás veszélyét a betegséggel együtt járó súlyos következmények mutatják: jelentős életminőség-romlás, depresszió, munkaképesség-csökkenés mellett a 2-es típusú cukorbetegség, szív-ér rendszeri betegségek, daganatos kórképek, mozgásszervi betegségek előfordulásá- 


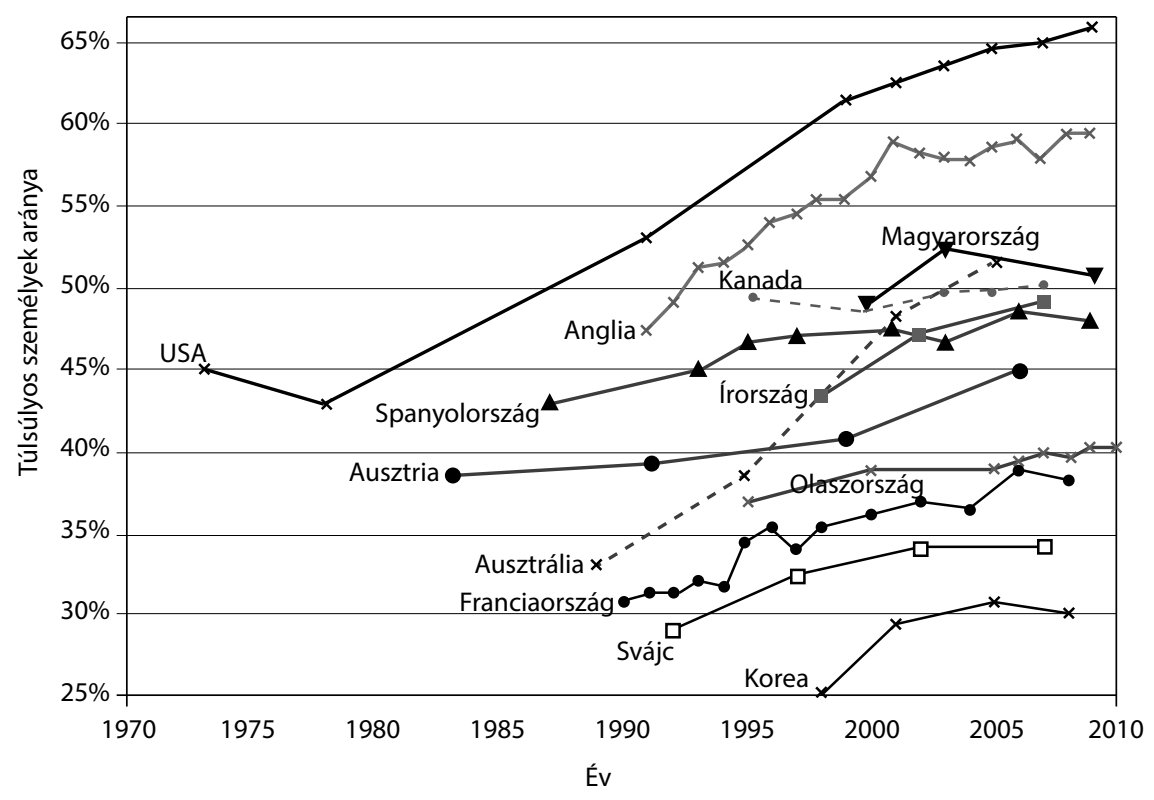

2. ábra

| A túlsúlyos személyek aránya az OECD-régióban (Forrás: OECD [7])

nak jelentős kockázatát rejti magában. 2010-ben a túlsúly és elhízás 3,4 millió halálesetért volt felelős, 4\%-os átlagos élettartam-csökkenést és 4\%-os rokkantsággal együtt járó életév-növekedést eredményezett.

\section{Elhízással összefüggő fokozott kockázat és szövődmények}

Anyagcsere-betegségek: diabetes, inzulinrezisztencia, dyslipidaemia, metabolikus szindróma, hyperuricaemia, krónikus gyulladások.

Sziv-ér rendszeri betegségek: hypertonia, szívkoszorúérbetegség, szívelégtelenség, stroke, vénás thromboembolia.

Légzőszervi betegségek: asthma bronchiale, hypoxia, alvási apnoe szindróma, elhízással összefüggő hypoventilatiós szindróma.

Daganatos kórképek: nyelőcső, vékonybél, vastagbél, végbél, máj, epehólyag, hasnyálmirigy, vese daganatai; leukaemia, myeloma multiplex, lymphoma. Nők esetében endometrium-, méhnyak-, petefészek-, emlőrák menopauzában. Férfiaknál: prosztatarák.

1. táblázat | Az elhízás BMI szerinti kategóriái felnőtteknél (WHO, 1997)

\begin{tabular}{ll}
\hline Kategória & $\mathrm{BMI}\left(\mathrm{kg} / \mathrm{m}^{2}\right)$ \\
\hline Alultáplált & $<18,5$ \\
Egészséges testsúly & $18,5-24,9$ \\
Praeobesitas & $25-29,9$ \\
Obesitas I. & $30-34,9$ \\
Obesitas II. & $35-39,9$ \\
Obesitas III. & $\geq 40$ \\
\hline
\end{tabular}

Gyulladásos és degeneratív mozgásszervi betegségek: A térd- és csípőízületi túlterhelés miatti fájdalmak.

Gyomor-bél betegségek: epehólyagot érintő kórképek, nem alkoholos zsírmáj és steatohepatitis, refluxbetegség, sérv.

A búgyutakat és nemi szerveket érintő betegségek: vizeletincontinentia, menstruációs zavarok, infertilitás, hirsutismus, polycystás ovarium szindróma. A terhesség során kialakulhat: gestatiós diabetes, praeeclampsia, macrosomia, magzati ártalmak, velőcső-záródási rendellenességek, szülési sérülések.

Pszichés és szociális következmények: alacsony önértékelés, szorongás és depresszió, stigmatizáció, diszkrimináció a munkahelyen, munkafelvétel, kollégiumi elhelyezés stb. során.

Egyéb: idiopathiás intracranialis hypertensio, proteinuria, nephrosis, bőrfertőzések, lymphoedema, szövődmények az altatás során, paradontosis.

Az elhízás oka komplex és multifaktoriális. Egyszerüen fogalmazva krónikus energiazavar, amely fokozott energiabevitel mellett csökkent energiafelhasználással magyarázható. Természetesen a helyzet ennél sokkal bonyolultabb, genetikai, epigenetikai, viselkedési zavarral áll összefüggésben, a környezeti stressz is jelentősen zavarhatja az energia-egyensúly kialakulását a zsírszövetben. Manapság a nagy energiatartalmú ételek, a nagyobb adagok, a fizikai aktivitás alacsony volta és az ülő életmód hozzájárul a kórkép kialakulásához [8].

\section{Diabesity}

A 2-es típusú cukorbetegség járványszerű terjedése Földünk egyik legnagyobb, a népesség egészségét veszélyeztető fenyegetése. A Nemzetközi Diabetes Szövetség 
(International Diabetes Federation - IDF) becslése szerint [9] 2015-ben világszerte 415 millió felnőtt cukorbeteg élt, 318 millió csökkent glükóztoleranciával terhelt személlyel számolhatunk. 2040-re a betegek száma 642 millióra nő, 10 személyből egy cukorbeteg lesz. Ha a betegség okozta halálozást vizsgáljuk, a cukorbetegség évi 5, a HIV/AIDS és tuberculosis 1,5 , a malária 0,6 millió halálesetért felelős. Jól ismert, hogy a betegség megelőzhető (lenne). Ismerjük a kockázati tényezőket: a túlsúly és az elhízás, mozgásszegény életmód, helytelen táplálkozási szokások, családi halmozódás, terhességi diabetes a kórelőzményben, valamint az idősebb életkor.

Sims és mtsai 1973-ban a cukorbetegség és elhízás együttes előfordulását „diabesity” elnevezéssel illették [10], utalva arra, hogy a két kórkép azonos okok miatt egymást súlyosbítva okoz egészségkárosodást.

A 2-es típusú diabetes prevenciója során az életmódi kezelésnek alapvető jelentősége van. Egy vizsgálat [11] gyermekkorban elemzi az életmód szerepét a 2 -es típusú diabetes későbbi kialakulásának megelőzésében. A prospektív, longitudinális, kohorszvizsgálatba (2005. júliustól 2008. decemberig) 630 gyermeket vontak be. A vizsgált gyermekek szüleiből legalább egyik szülő diabeteses volt. Az adatokat kiinduláskor (8-10 éves korban), majd két évvel később összegezték. A fitneszt a maximális oxigénfelhasználással és a test zsírtartalmának elemzésével, a napi televízió-, videó-, számítógép-használattal elemezték. Az inzulinérzékenységet HOMA-módszerrel meghatározott inzulinrezisztencia és OGTT-alapú Matshuda-inzulinszenzitivitási index felhasználásával mérték. Az inzulinszekréciót a görbe alatti terület inzulin-glükóz érték mérésével határozták meg az első 30 percben és az OGTT-t követő két órában. 630 gyermek adatai álltak rendelkezésre. 54,4\% fiú; normális testsúlyú 56,2\%; túlsúlyos 19,2\%; elhízott 22,7\%. Az elhízás és a testsúly változásának fó prediktora volt az inzulinelválasztás dinamikus változása. Minden addicionális 1\%-os testzsírnövekedés 8-10 éves korban az inzulinérzékenységet csökkentette $2,9 \%$-kal. A fizikai aktivitás és a képernyő előtt töltött idő mérséklése egyértelmúen javította az inzulinérzékenységet a test zsírtartalmának csökkentése révén.

A diabetes megelózésében a testsúly csökkentése, az ideális súly megtartása mellett a fizikai aktivitás fokozása és a helyes táplálkozás alapvetően fontos. A kezelés célja nemcsak a testzsír csökkentése, hanem az életminőség javulása mellett az obesitassal összefüggő kockázat mérséklése. Jelentős haszon érhető el még mérsékelt súlycsökkentés (a kezdeti testsúly 5-10\%-a) esetén is. Az obesitas kezelésének nem a testtömegcsökkentés a fó célja, nagyobb figyelmet kell fordítani a derékkörfogat csökkentésére és a testösszetétel zsírtartalmára. Jól ismert az abdominalis (férfias, alma típusú, centrális) obesitas összefüggése az inzulinérzékenység csökkenése/ hyperinsulinaemia kórfolyamatával. Sikeres kezelés esetén a vércukor- és vérzsíreltérések, vérnyomás, alvási apnoe szindróma tünetei, a mozgásszervi panaszok egya- ránt javulnak. A terápia fó irányai: a túlsúlyos személyeknél a további testsúlynövekedés megállítása, az 5-10\%-os testsúlycsökkenés fél év alatt reális célkitúzés lehet, fontos megakadályozni a testsúly relapsusát, amely rendkívül gyakori.

A speciális kezelés lehetőségei között kiemelten fontos a táplálkozással összefüggő tanácsadás:

- Csökkentsük az ételek és italok energiatartalmát!

- Csökkentsük az adagok nagyságát!

- Kerüljük az étkezések közötti nassolást!

- Ne hagyjuk ki a reggelit és kerüljük az esti étkezést!

- Sikeresen menedzseljük a kontrollvesztés következtében kialakuló falási rohamokat!

A kalóriatartalmú édesítőszerek helyettesítése alacsonyabb vagy kalóriamentes táplálékkiegészítőkkel elősegíthetik a testsúly csökkentését vagy megtartását az energiabevitel csökkentése útján [12]. Az utóbbi időben megjelent közleményekben az NNS és a testsúly összefüggése nem egységes megítélést tükröz. Randomizált, kontrollált tanulmányok (RCT) és prospektív csoportelemzések történtek a kérdés tisztázására. Az irodalom szisztematikus feldolgozását követően 15 RCT és 9 prospektív csoportanalízis foglalkozott az NNS asztali édesítőként történő felhasználásával. A metaanalízis célja a testsúly és testösszetétel alakulása NNS fogyasztása esetén kontrollcsoporttal összehasonlítva. Az eredmények alapján az NNS mérsékelten, de szignifikáns mértékben csökkentette az összes kimeneti végpontot, beleértve a testsúlyt $(-0,80 \mathrm{~kg} ; 95 \% \mathrm{CI}:-1,17,-0,43)$, BMI-t $(-0,24 ; 95 \%$ CI: $-0,41,-0,07)$, zsírtömeget $(-1,10 \mathrm{~kg}$; $95 \%$ CI: $-1,77,-0,44)$ és derékkörfogatot $(-0,83 \mathrm{~cm}$; 95\% CI: $-1,29,-0,37)$. A prospektív kohorszvizsgálatok során NNS bevitelét nem találták a testsúly és zsírtömeg szignifikáns csökkenésével összefüggésben, de a BMI esetében ez kimutatható volt $(0,03 ; 95 \%$ CI: $0,01,0,06)$.

Közismert, hogy a cukorral édesített üdítőitalok túlzott fogyasztása és a 2-es típusú cukorbetegség kialakulásának kockázata között szoros összefüggés állapítható meg. A metaanalízis [13] célja az volt, hogy tisztázza, a cukorral édesített üdítőitalok fogyasztásával együtt járó életstílus fokozza-e a kockázatot vagy hasonló összefüggés megállapítható-e a mesterséges édesítőszerek fogyasztása során, a testtömegindex változásának tükrében. 11 közlemény elemzése történt, a napi felhasználást ml-ben vizsgálták, a relatív kockázatot random hatás metaanalízissel vizsgálták. A relatív kockázat a cukorral és NNS-sel édesített üdítőitaloknál $1,20 / 330 \mathrm{ml}$ naponta ( $95 \%$ CI: $1,12,1,29, \mathrm{p}<0,001)$ és $1,13 / 330 \mathrm{ml}$ naponta ( $95 \%$ CI: $1,02,1,25, \mathrm{p}=0,02)$. A fentiek alapján a szerzők nem tudtak egyértelmú összefüggést találni a diabeteskockázat növekedése, az életmód, a cukorral édesített üdítőitalok és az energiamentes üdítóitalok fogyasztása között.

A 2-es típusú cukorbetegség kialakulásának kockázatfokozódását több szerző összefüggésbe hozta a cukorral édesített gyümölcsszörpök fogyasztásával. A közlemény [14] négy vizsgálat, 191686 személy, köztük 12375 cu- 
korbeteg adatait elemezte, akik cukorral édesített üdítőitalokat fogyasztottak. Kontrollként ugyancsak négy közlemény, 137663 személy és 4906 cukorbeteg adatait dolgozták fel, akik csak 100\%-os gyümölcslét fogyasztottak. A cukorral édesített gyümölcslé fogyasztása szignifikánsan összefüggött a 2-es típusú cukorbetegség kockázatnövekedésével $(\mathrm{RR}=1,28,95 \% \mathrm{CI}=1,04-1,59$, $\mathrm{p}=0,02)$ versus a $100 \%$-os cukormentes gyümölcslé rendszeres fogyasztása során kockázatfokozódást nem találtak $(\mathrm{RR}=1,03,95 \% \mathrm{CI}=0,9-1,18, \mathrm{p}=0,62)$. A szerzők arra a következtetésre jutottak, hogy korlátozni kell a cukorral édesített gyümölcslevek fogyasztását a 2-es típusú diabetes kialakulásának kockázatcsökkentése céljából.

$\mathrm{Az}$ alacsony energiatartalmú édesítőszereket széles körben használják, ugyanakkor használatukat gyakran támadják fóként a laikus sajtóban, felvetik, hogy az édes íz iránti vágyat serkentik és nem alkalmasak a testsúly kontrolljára. Az NNS hatékonyságát és biztonságosságát randomizált, kontrollált tanulmányok igazolták [15], beleértve az agyi képalkotó eljárásokat. A közlemények áttekintése alapján az NNS az édesség iránti vágyat nem fokozza, a cukortartalmú ételek fogyasztását inkább csökkenti és segíti a testsúly megtartását.

Egy nagy betegszámot felölelő, 17 kohorsz vizsgálata során (38 253 eset, 10126754 év) a cukorral édesített italok fogyasztása a 2 -es típusú diabetes 18\%-os kockázatának fokozódásával járt együtt napi egy adag esetén is (95\% CI: 9-28\%). A közlemény [16] arra utal, hogy az Amerikai Egyesült Államokban 10 év alatt 20,9 millió új 2 -es típusú diabetes megjelenése várható, amelyből 1,8 millió a cukorral édesített italok túlzott fogyasztásának rovására írható, és az Egyesült Királyságban 2,6 millió esemény közül 79000 ugyanilyen okok miatt alakul ki. A részletesebb elemzés arra is kitér, hogy a cukorral ízesített italok rendszeres, túlzott mértékű fogyasztása és a kockázat növekedése független a testsúlytól.

Egy érdekes vizsgálat során a szerzők NNS rendszeres használatát hasonlították össze víz fogyasztásával egy testsúlyt csökkentő egyéves program keretében [17]. 303 stabil testsúlyú, túlsúlyos és elhízott személy esetében NNS-tartalmú üdítőt vagy folyadékot fogyaszthattak a résztvevők. Naponta legalább $710 \mathrm{ml}$ vizet vagy NNS-tartalmú üdítőt kellett elfogyasztaniuk. A vizsgálat befejezésekor, egy év után, az energiamentes üdítőt fogyasztók csoportjában nagyobb súlycsökkenést találtak. A vízfogyasztó csoportban $2,45 \pm 5,59 \mathrm{~kg}$ volt a súlycsökkenés, míg az NNS-csoportban 6,21 $\pm 7,65 \mathrm{~kg}$ $(\mathrm{p}<0,001)$. A vizsgálati eredmények azt sugallják, hogy az NNS-tartalmú üdítők fogyasztása hatékony eszköz lehet a testsúly megtartása/súlycsökkentés céljára a testsúlykontrollprogram részeként.

Az Amerikai Szív Társaság és az Amerikai Diabetes Társaság által kiadott állásfoglalás szerint [5] kevés vizsgálat áll rendelkezésre az édesítőszerekkel kapcsolatban. Nem könnyű a klinikai vizsgálatok megtervezése az NNS használatával kapcsolatban, mások a diétás összetevők, az ételadagok nagysága, zsír-, fehérje- és szénhidráttartalma jelentősen változhat. Nem egyszerú az NNS versus hozzá adott cukortartalommal rendelkező italokkal, ételekkel összehasonlító vizsgálatokat tervezni. A legtöbb vizsgálat a diétás üdítőitalokat hasonlította össze a cukortartalmú hasonló készítményekkel. A publikált irodalmi adatok egy része állatkísérleteken alapul, az esetleges potenciális toxicitás elemzése történt meg.

\section{Étvágy, éhségérzet és energiabevitel}

Az NNS-tartalmú ételek és italok használata sikeresen csökkentheti a hozzáadott cukorból eredő kalóriát és segít elkerülni a kompenzáló energiabevitelt az étkezés során vagy később. Ha diétás üdítőitalt fogyasztunk, 100 kalóriával kevesebb energiát viszünk be $30 \mathrm{ml}$-enként. Felmerült, hogy az éhségérzet fokozódásával 50-100 vagy 200 kalória pluszenergia-bevitel is történhet. Mattes kritikai vizsgálatnak vetette alá [18] a kompenzáló étvágyfokozódást és táplálékbevitelt. A való életben a táplálkozással kapcsolatos számtalan tényező elemzése során arra a következtetésre jutott, hogy a korábbiakban említett fokozottabb energiabevitel nem hozható összefüggésbe az NNS használatával. Az ezzel kapcsolatos további vizsgálatok, köztük a 12 klinikai vizsgálat metaanalízise során kiderült, hogy az esetlegesen fennálló kompenzációs kalóriabevitel még mindig kisebb, mint az NNS használata során bevitt alacsonyabb kalóriaszintú táplálék mennyisége. 21 túlsúlyos felnőtt vizsgálata során, ha az energiabevitel $28 \%$-a cukor formájában történt, 10 hét után jelentősen nőtt a testsúly, a zsírtömeg és a vérnyomás. Ezek a hatások nem alakultak ki 20 túlsúlyos személynél, akik cukor helyett NNS-t használtak egyébként hasonló jellegú ételek fogyasztása mellett. Jelenleg, a szerzők véleménye szerint, nem áll rendelkezésre elegendő adat a cukortartalmú édesítőszerek NNS-sel történő helyettesítésével kapcsolatban az étvágy, az energia-egyensúly, testtömeg és kardiometabolikus kockázatcsökkentés vonatkozásában.

A közelmúltban megjelent szakmai állásfoglalások [8, 19-21] alapján megállapítható:

- Az NNS-ek nem fokozzák az étvágyat és nem befolyásolják a jóllakottságérzést.

- Az NNS hozzájárulhat az energiabevitel csökkentéséhez, ha magas energiatartalmú összetevők helyettesítésére használják.

- Ha testsúlycsökkentő program részeként az egészséges diétába illesztik az NNS-tartalmú élelmiszereket, segíthet a súlycsökkentésben.

- Az NNS nem emeli a postprandialis vércukor- és inzulinszintet egészséges és diabeteses személyekben.

- Az NNS eredményesen használható ételek, üdítőitalok, fogpaszta és gyógyszerek édesítésére, mivel a fogszuvasodást megelőzi és a száj savtartalmát nem fokozza.

A hozzáadott cukormennyiség limitálása rendkívül fontos stratégiai feladat az ideális táplálkozás és az egész- 
séges testsúly megtartása érdekében. A szénhidrátbevitel ellenőrzése, amelybe beletartozik a hozzáadott cukormennyiség csökkentése, az ideális szénhidrát-anyagcsere elérésének fontos eszköze az Amerikai Diabetes Társaság szakmai ajánlása [22] szerint. A rendelkezésre álló adatok egy része azt sugallja, hogy az NNS használata strukturált diétában a hozzáadott cukrok helyett, mérsékelt energiabevitel-csökkenést és súlycsökkenést eredményezhet. Az NNS-tartalmú italok és ételek általános diétába történő beillesztése az elönyök és kockázatok figyelembevételével történjen. Az eddigi ismeretek alapján az NNS-tartalmú élelmiszerek képesek a hozzáadott cukor mennyiségét helyettesíteni és a totális energiabevitelt, a testsúly megtartását és súlykontrollt előnyösen befolyásolni. Mindez akkor valósulhat meg eredményesen, ha nem kíséri kompenzatorikus kalóriabevitel.

A Magyar Diabetes Társaság szakmai irányelve [23] is biztonságosnak tekinti a cukorbetegek dietoterápiája során alkalmazott NNS-eket: „A mesterséges édesítőszerek és a velük készült energiamentes italok fogyasztása megengedett. Időről időre megjelennek egyes származékok kevéssé biztonságos voltáról szóló tudósítások, ezeket azonban adatok kellően nem támasztják alá. Nemzetközi szakértő testületek állásfoglalása alapján e készítmények szokásos napi adagú használata egészségkockázatot nem jelent."

Anyagi támogatás: A szerző a közlemény megírásáért a Nemzetközi Édesítőszer Szövetségtől anyagi támogatásban részesült.

A szerző a cikk végleges változatát elolvasta és jóváhagyta.

Érdekeltség: A szerzőnek nincsen érdekeltsége.

\section{Irodalom}

[1] Bartoshuk, L. M., Beauchamp, G. K.: Chemical senses. Annu. Rev. Psychol., 1994, 45, 419-449.

[2] World Health Organization: Guideline: Sugars intake for adults and children. WHO, Genera, 2015. http://apps.who.int/iris/ bitstream/10665/149782/1/9789241549028_eng.pdf?ua=1

[3] Sarkadi Nagy, E., Bakacs, M., Illés, É., et al.: Hungarian Diet and Nutritional Status Survey - the OTAP2009 study. II. Energy and macronutrient intake of the Hungarian population. [Országos Táplálkozás és Tápláltsági Állapot Vizsgálat - OTÁP2009. II. A magyar lakosság energia- és makrotápanyag-bevitele.] Orv. Hetil., 2012, 153(27), 1057-1067. [Hungarian]

[4] Kiss-Tóth, B.: Survey of the nutritional status and physical activity of children aged between 4 and 10 years - summary of data on breakfast consumption. [Négy-tíz éves gyermekek táplálkozásának és fizikai aktivitásának felmérése - reggelizési szokásokra vonatkozó eredmények összefoglalója.] Új Diéta, 2014, 23(4), 18-20. [Hungarian]

[5] Gardner, C., Wylie-Rosett, J., Gidding, S. S., et al.: Non nutritive sweeteners: current use and health perspectives: A scientific statement from the American Heart Association and the American Diabetes Association. Circulation, 2012, 126(4), 509-519.
[6] Yumuk, V., Tsigos, C., Fried, M., et al.: European guidelines for obesity management in adults. Obes. Facts, 2015, 8(6), 402424.

[7] The OECD report Obesity and the economics of prevention: fit not fat. www.oecd.org/health/fitnotfat

[8] Jensen, M. D., Ryan, D. H., Apovian, C. M., et al.: 2013 AHA/ ACC/TOS Guideline for the Management of Overweight and Obesity in Adults. A report of the American College of Cardiology/American Heart Association Task Force on Practice Guidelines and The Obesity Society. Circulation, 2014, 129(25 Suppl. 2), S102-S138.

[9] International Diabetes Federation: IDF Diabetes Atlas. 7th edition. International Diabetes Federation, Brussels, 2015.

[10] Sims, E. A., Danforth, E. Jr., Horton, E. S., et al.: Endocrine and metabolic effects of experimental obesity in man. Recent Prog. Horm. Res., 1973, 29, 457-496.

[11] Henderson, M., Benedetti, A., Barnett, T. A., et al.: Influence of adiposity, physical activity, fitness, and screen time on insulin dynamics over 2 years in children. JAMA Pediatr., 2016, 170(3), 227-235.

[12] Miller, P. E., Perez, V.: Low-calorie sweeteners and body weight and composition: a meta-analysis of randomized controlled trials and prospective cohort studies. Am. J. Clin. Nutr., 2014, 100(3), 765-777

[13] Greenwood, D. C., Threapleton, D. E., Evans, C. E., et al.: Association between sugar-sweetened and artificially sweetened soft drinks and type 2 diabetes: systematic review and dose-response meta-analysis of prospective studies. Br. J. Nutr., 2014, 112(5), 725-734.

[14] Xi, B., Li, S., Liu, Z., et al.: Intake of fruit juice and incidence of type 2 diabetes: a systematic review and meta-analysis. PLoS ONE, 2014, 9(3), e93471.

[15] Bellisle, F.: Intense sweeteners, appetite for the sweet taste, and relationship to weight management. Curr. Obes. Rep., 2015, $4(1), 106-110$

[16] Imamura, F., O'Connor, L., Ye, Z., et al.: Consumption of sugar sweetened beverages, artificially sweetened beverages, and fruit juice and incidence of type 2 diabetes: systematic review, metaanalysis, and estimation of population attributable fraction. BMJ, 2015, 351, h:3576

[17] Peters, J. C., Beck, J., Cardel, M., et al.: The effect of water and non-nutritive sweetened beverages on weight loss and weight maintenance: a randomized clinical trial. Obesity, 2016, 24(2), 297-304.

[18] Mattes, R.: Effects of aspartame and sucrose on hunger and energy intake in humans. Physiol. Behav., 1990, 47(6), 1037-1044.

[19] Gibson, S., Drewnowski, A., Hill, J., et al.: Consensus statement of benefits of low-calorie sweeteners. Nutr. Bull., 2014, 39, 386389.

[20] Fitch, C., Keim, K. S.: Position of the Academy of Nutrition and Dietetics: Use of nutritive and non nutritive sweeteners. J. Acad. Nutr. Diet., 2012, 112(5), 739-758.

[21] Serra-Majem, L., Riobó Serván, P., Belmonte Cortés, S., et al.: Chinchón declaration; decalogue on low- and no-calorie sweeteners (LNCS). Nutr. Hosp., 2014, 29(4), 719-734.

[22] American Diabetes Association: Standards of medical care in diabetes - 2016. Diabetes Care, 2016, 39(Suppl. 1), S1-S112.

[23] Gaál, Zs., Gerố, L., Hidvégi, T., et al.: Diagnosis of diabetes mellitus, treatment and care of diabetic adults. Professional guideline of the Hungarian Diabetes Society. 2014. [A diabetes mellitus kórismézése, a cukorbetegek kezelése és gondozása felnőttkorban. A Magyar Diabetes Társaság szakmai irányelve. 2014.] Diabetologia Hungarica, 2014, 22(Suppl. 1), 1-84. [Hungarian]

(Hidvégi Tibor dr., Petz Aladár Megyei Oktató Kórház, Győr, Vasvári Pál u. 2-4., 9024 e-mail: hidvegi@t-online.hu) 